\title{
KONSELING KELOMPOK EMOTIONAL INTELLEGENCE PADA TIPE KEPRIBADIAN INTROVERT
}

\author{
Ainun Sakinah \\ Mahasiswa Pascasarjana Universitas Islam Negeri Sunan Kalijaga \\ e-mail: ainunsakinah78@gmail.com
}

\begin{abstract}
Counselling groups in practice put more emphasis on the attitude of openness and trust and the attitude of maintaining secrecy than individual counselling, so group counselling was able to facilitate individuals to develop an attitude of openness. Different personality types are different in managing their emotions. Likewise, the type of introvert and extrovert personality, if extroverts tend to be flexible and easy to socialize, introverts are not. Personal introverts that are identical with closed attitudes and lack of socialization. But some introverts develop emotions so they are able to adapt to the new environment, even though for that they need more time to reach that stage. This research is a type of library research or library research, using a reference analysis approach. Based on this research, introverted emotional intelligence is understanding the environment, planning approaches, doing what has been planned well, then evaluating the steps that have been taken. So that introverts have good emotional intelligence with a detailed process called relational understanding.
\end{abstract}

Keywords: Group Counseling, Emotional Intelligence, Introverted Personality 


\begin{abstract}
Abstrak
Group counseling dalam praktiknya lebih menekan adanya sikap keterbukaan dan kepercayaan serta sikap menjaga rahasia daripada konseling individu, sehingga konseling kelompok mampu memfasilitasi individu untuk membangun sikap keterbukaan. Berbeda tipe kepribadian maka berbeda pula pengelolaan emosinya. Begitu juga tipe kepribadian introvert dan ekstrovet, jika ekstrovert cenderung bersifat luwes dan mudah bersosialisasi maka introvert tidak demikian. Pribadi introvert yang identik dengan sikap tertutup dan kurang bersosialisasi. Namun beberapa pribadi introvert dalam mengembangkan emosi sehingga mampu beradaptasi dengan lingkungan baru, meski untuk itu mereka lebih membutuhkan waktu lebih untuk mencapai tahap tersebut. Penelitian ini jenis penelitian library research atau penelitian kepustakaan, menggunakan pendekatakan analisis referensi. Berdasarkan penelitian ini kecerdasan emosi (emotional intellegance) pribadi introvert adalah memahami lingkungan, merencanakan pendekatan, melakukan apa yang sudah direncanakan dengan baik, kemudian mengevaluasi langkah yang telah dilakukan. Sehingga pribadi introvert memiliki kecerdasan emosi yang baik dengan proses yang detail yang disebut dengan pemahaman relasional.
\end{abstract}

Kata Kunci: Konseling Kelompok, Emotional Intellegance, Kepribadian Introvert 


\section{A. Pendahuluan}

Pembahasan mengenai emosi merupakan hal yang sangat menarik dan patut untuk terus menerus dikupas dan diperdalam. Karena emosi merupakan aspek sentral bagi masingmasing individu dalam kehidupan, hal ini menjadikan aspek emosi perlu mendapatkan perhatian penting oleh para pendidik dan orang tua sehingga perlu pemahaman yang komprehensif terhadap stimulus emosi individu. Emosi bukan hanya penting dalam kehidupan individu, akan tetapi juga emosi memiliki beberapa peran penting bagi kehidupan individu, pertama emosi berperan sebagai survival untuk bertahan hidup. Selain itu, emosi juga berperan sebagai energizer atau pembangkit energi yang mana energy ini dapat memberikan individu gairah dalam kehidupannya. Emosi dalam perannya sebagai energizer dapat memberikan individu berupa rasa semangat dalam melakukan kegiatan sehari-hari. Emosi sendiri perlu dikembangkan supaya aspek dan fungsinya bisa menjadi lebih sehat. Perkembangan emosi individu bisa muncul dari faktor internal dan eksternal. Mengutip dari buku yang ditulis oleh Riana Mashar, Hurlock (1991) dan Lazarus (1991) menyatakan bahwa perkembangan emosi itu dapat terbentuk dari dua faktor yakni faktor proses maturation atau kematangan dan juga proses belajar. Dari kedua faktor ini, Hurlock lebih menekankan pentingnya pengaruh belajar untuk perkembangan emosi, hal ini karena belajar merupakan faktor yang dapat dikendalikan. ${ }^{1}$

Pada hakikatnya setiap individu berbeda dengan ciri khasnya masingmasing, perbedaan ini tidak hanya dari aspek fisik dan psikis. Maka dari itu, emosiyangterdapatpadasetiapindividu tidak lepas dari aspek kepribadian individu tersebut. Sepeti yang sering kali didengar, terdapat dua kepribadian yakni Ekstrovet dan Introvet. Individu dengan tipe kepribadian introvert cenderung pendiam, pemalu, dan merasa tidak nyaman disituasi sosial. Individu dengan tipe kepribadian introvert akan bisa membuka diri dengan orang disekitarnya, namun hal ini tergantung dari pengalaman yang dialami individu. Berbeda dari individu dengan tipe kepribadian ekstrovert yang mana tipe kepribadian ini merupakan tipe kepribadian yang terbuka dan mudah bersosialisasi dengan lingkungan sekitar. Sehingga dari sini pribadi introvert akan perlu upaya lebih untuk mengendalikan bahkan mengembangkan emosi, pada

1 Riana Mashar, Emosi Anak Usia Dini dan Strategi Pengembangannya, (Jakarta: Kencana, 2011), 24. 
saat mereka merasa tidak nyaman dan lebih cocok untuk pribadi ekstrovet.

Permasalahannya adalah tidak semua individu dengan tipekepribadian introvert selalu menarik diri atau tidak dapat bersosialisasi dengan lingkungan baru yang membuatnya tidak nyaman. Beberapa individu dengan kepribadian introvertyangmerekadapatmasukpada lingkungan baru yang bertolak dengan tipe kepribadian mereka. Tetapi pada intinya beberapa individu memiliki kecerdasan emosi yang membentuk mereka menjadi pribadi introvert yang luwes akan lingkungan baru dan membantu beradaptasi. Sehingga mereka dapat memahami emosi dan membantu mereka membentuk hubungan dengan orang lain.Pribadi introvert yang terlihat pasif dan jarang memperlihatkanemosidenganekspresi wajah ternyata jusru memiliki cara tersendiri dalam mengendalikan emosi di hadapan orang lain, sehingga hal ini menjadikan pribadi introvert dianggap tidak dapat mengungkapkan atau mengekspresikan emosinya. ${ }^{2}$ Rosida dan Astuti menjelaskan bahwa tidak adanya perbedaan dalam penerimaan teman sebaya antara pribadi introvert dan ektrovert, hal ini bertolak belakang

2 Grita Ratriana Melinda, "Kontrol Emosi Pada Mahasiswa Yang Memiliki Tipe Kepribadian Introvert di Yogyakarta”, Jurnal Riset Mahasiswa Bimbingan dan Konseling, (Vol.3. No. 7.Thn. 2017), 281. dengan asumsi masyarakat yang menilai bahwa kepribadian ekstorvert lebih baik dari pribadi introvert. Demikian ini bukan karena adanya bentuk perilaku positif maupun negatif melainkan dilatar belakangi oleh perbedaan arah energi psikis individu sehingga membentuk perilaku sosial masing-masing dalam memberikan respon terhadap lingkungan. ${ }^{3}$

Bimbingan dan konseling merupakan layanan bantuan yang diberikan kepada peserta didik baik secara perorangan maupun secara kelompok. Sejalan dengan pendapat tersebut diatas, proses konseling harusnya bertindak secara efektif bukan hanya dari segi aspek individu tetapi juga aspek sosial individu. Namun pada realitanya tidak semua lembaga seperti sekolah mamberikan layanan bimbingan dan konseling. Sedangkan bimbingan dan pribadi sosial merupakan layanan bimbingan dan konseling untuk membantu murid agar menemukan dan mengembangkan pribadi yang beriman dan bertaqwa kepada Tuhan, mantap, dan mandiri. ${ }^{4}$ Dalam sebuah penelitian

3 Edwina Rosida dan Tri Puji Astuti, "Perbedaan Penerimaan Teman Sebaya Ditinjau Dari Tipe Kepribadian Ekstrovert dan Introvert", Jurnal Empati, (Vol.4. No. 1.Thn. 2015), 80 .

4 Muhammad Nursalim, Bimbingan dan Konseling Pribadi-Sosial, (Yogyakarta: Ladang Kata, 2012), 17. 
layanan bimbingan di sekolah belum terlaksana dengan baik dikarenakan kuantitasgurubimbingandankonseling sebanyak satu orang untuk semua kelas, sehingga layanan bimbingan kelompok di sekolah tersebut belum efektif dalam memfasilitasi individu mencapai kematangan emosi. ${ }^{5}$ Maka dalam bimbingan dan konseling kelompok tidak hanya memperhatikan kualitas dan profesionalitas konselor melainkan juga kuantitas konselornya. Tidak akan efektif apabilan dengan anggota kelompok 10 konseli akan tetapi memiliki satu orang konselor.

Berangkat dari sinilah, kemudian para konselor menerapkan konseling kelompok karena dirasa mampu memberikan layanan konseling dari segi pribadi atau individual dan juga segi sosial individu.Dalam penelitian Ali Masrohan dan Anjar Raharyanti yang mengunakan konseling kelompok dengan menggunakan terapi realitas mampu meningkatkan kedisiplinan belajar siswa dan meningkatkan motivasi berprestasi siswa dalam pelajaran matematika.

Untuk itu, erat kaitannya dengan tipe kepribadian ekstrovert dan introvertyangmanakeduanyasangatlah

5 Annajmi Alfatih, Taufik, dan Indra Ibrahim, Peningkatan Kematangan Emosi Anak Bungsu Melalui Layanan Bimbingan Kelompok, Jurnal Konseling dan Pendidikan, (Vol.4. No. 1.Thn. 2015), 50 . berbeda terutama dalam aspek emosi serta mengkorelasikan permasalahan tersebut dengan melakukan kegiatan konseling kelompok, dengan tujuan peneliti ingin mengetahui kecerdasan emosi pada tipe kepribadian introvert melalui konseling kelompok. Dan mengkaji peran konseling kelompok dalam membantu pribadi introvert tersebut. Bagaimana tipe kepribadian introvert menyesuaikan diri dengan lingkungan sosialnya yang tidak sesuai dengan pribadinya yang pemalu, pendiam, dan cenderung membuatnya merasa tidak nyaman.

\section{B. Konseling Kelompok}

Pada masa ini tekhnologi sudah sangat berkembang pesat tidak hanya mengatasi masalah dan menggeser tatanan kehidupan baru bagi manusia terdahulu, tetapi juga menciptakan tatanan kehidup baru bagi manusia modern. Masa ini sering disebut dengan era milenial. Era milenial sendiri merupakan istilah untuk tatanan peradaban manusia modern yang menjadikan teknologi sebagai sahabat dalam menjalankan aktivitas sehari-hari. Tidak terkecuali bidang konseling, pembaruannya bisa kita temui dari aspek teori, teknik, media, sampai pada masalah yang dihadapi klien. Seperti yang sudah dikenal oleh masyarakat mengenai cyber konseling 
atau konseling dengan menggunakan dunia maya, atau dengan melakukan konseling kelompok. Sehingga dengan modifikasi kegiatan konseling diharapkan dapat mencapai tujuan atau harapan yang diinginkan secara efektif.

Shertzer dan Stone mengartikan bimbingan sebagai "process of helping an individual to understand himself and his world". Dalam arti lain bimbingan merupakan proses pemberian bantuan kepada individu supaya mampu memahami diri dan lingkungannya. Sedangkan konseling "is an interaction process which facilitates meaningful understanding of self and environment and result in the establishment and clarification of goals and values of future behavior."' Konseling merupakan hubungankolaboratif yangprofessional dilakukan konselor untuk memfasilitasi konseli mempelajari serta memahami kopetensi diri, mampu mengambil keputusan, memecahkan masalah, serta membentuk kembali perilaku baru yang lebih baik.

Dalam bidang konseling, berkelompok dapat menjadi suatu sarana untuk membantu manusia dalam mencapai perkembangan serta menjadi terapi guna mengatasi

6 Syamsu Yusuf dan Juntika Nurihsan, Landasan Bimbingan dan Konseling, (Jakarta: PT Rosda Karya, 2008), 40. persoalan psikologi manusia yang. Kegiatan ini banyak dikenal dengan istilah konseling kelompok. Sejalan dengan itu Kurnantomenjelaskan bahwa program konseling kelompok dapat memberikan individu berbagai macam pengalaman kelompok yang membantu mereka belajar berfungsi secara efektif, mengembangkan toleransi terhadap stress dan kecemasan, dan dapat menemukan kepuasan dalam bekerja dan hidup bersama orang lain. ${ }^{7}$ Pendapat yang lain mengatakan bahwa bimbingan kelompok juga dapat membantu individu dalam mengenali diri sendiri terutama mengenali emosi-emosi yang sering muncul pada dirinya. ${ }^{8}$

Berdasarkan penjelasan mengenai konseling kelompok yang dirasa secara efektif dapat membantu individu mengenali diri, memberikan pengalaman baru, dan menyadarkan bahwa terdapat kepuasan tersendiri dapat bekerja dan hiudp berdampingan dengan orang lain. Maka dari itu bimbingan konseling kelompok dapat membantu mengenali kecerdasan emosi atau emotional intellegance individu dengan tipe kepribadian introvert. Karena peran konseling

$7 \quad$ Kurnanto, Konseling Kelompok, (Bandung: Alfabeta, 2013), 2.

8 Annajmi Alfatih, Taufik, dan Indra Ibrahim, Peningkatan Kematangan Emosi Anak Bungsu Melalui Layanan Bimbingan Kelompok..., 51 . 
kelompok lebih membawa konseli kepada pola interaksi individu satu dengan individu yang lain dan dalam konseling kelompok mengangkat unsur pribadi sosial yakni adanya timbale balik.

\section{Kecerdasan Emosi}

Kecerdasan emosional pertama kali dilontarkan pada tahun 1990 oleh psikolog Peter Salovey dari Harvard University dan John Mayer dari University of New Hampshire untuk menerangkan kulitas-kualitas emosional yang tampaknya penting bagi keberhasilan. Kualitas-kualitas ini antara lain adalah: empati, mengungkapkan dan memahami perasaan, mengendalikan amarah, kemandirian, kemampuan menyesuaikandiri, diskusi,kemampuan memecahkan masalah antar pribadi, ketekunan, kesetiakawanan, keramahan, sikap hormat.

Goleman berpendapat bahwa emosi merujuk pada suatu perasaan dan pikiran-pikiran khasnya, suatu keadaan biologis dan psikologis serta serangkaian kecenderungan dalam bertindak. Menurutnya berbagai masalah yang dihadapi masyarakat dunia pada saat ini bukan pada emosi, melainkan penerapannya secara tepat dalam berbagai situasi yang ada. Sedangkan dalam penemuan Ekman ekspresi wajah tertentu untuk emosi takut, marah sedih dan senang dikenali oleh bangsa-bangsa seluruh dunia dengan budayanya masing-masing. ${ }^{9}$ Merujuk pada pernyataan Goleman pada intinya emosi itu merujuk pada perasaan yang membentuk kecenderungan individu dalam bertindak, menunjukkan bahwa emosi erat kaitannya dengan tindakan. Jika individu dengan emosi yang baik dan ia mampu mengendalikan, maka tindakan yang dihasilkan emosi akan berupa tindakan yang baik pula. Tetapi, jika individu tersebut tidak dapat mengendalikan emosi maka tindakan yang dihasilkan dari emosi akan berupa tindakan yang tidak baik. Seperti halnya rasa takut amarah, bahagia sedih dan cinta merupakan hasil dari dinamika emosi manusia. Gejala-gejala dari emosi ini secara tidak langsung akan tampak pada perilaku. Hal ini didukung oleh pernyataan yang mengutip dari buku Alwisol dalam bukunya Alwisol menyatakan bahwa tidak ada tingkah laku yang terjadi begitu saja tanpa didasari faktor anteseden, sebab musabab, pendorong,

9 Adya Baskara, Helly P Soetjipto, dan Nuryati Atamimi, "Kecerdasan Emosi Ditinjau Dari Keikutsertaan Dalam Program Meditasi”, Jurnal Fakultas Psikologi UGM, (Vol.35.No.2. 2015), 102. 
motivator, sasaran-tujuan dan hal yang melatarbelakangi. ${ }^{10}$

Lazarus mengategorikan emosi menjadi dua kategori yakni emosi primer (basic) dan emosi sekunder (derived). Emosi primer merupakan emosi yang ada pada spesies mamalia, sedangkan emosi sekunder merupakan kombinasi dari beberapa emosi primer. ${ }^{11}$ Sedangkan Darwin menjelaskankarakteristikemosiprimer adalah emosi primer merupakan emosi yang bersifat biologis (ada sejak lahir), emosi primer merupakan emosi yang dapat diekspresikan melalui ekspresi wajah, emosi primer sangat berkaitan dengan saraf otak yang berdampak dan berhubungan dengan aktivitas sistem otonom. Dari jenis emosi tersebut jika dikaitkan dengan kecerdasan emosi, bahwa kecerdasan emosi atau emotional intellegance meliputi mengidentifikasi dan memberi nama perasaan, mengungkapkan perasaan, menunda pemuasan, mengendalikan dorongan hati, serta mengetahui perbedaan antara perasaan dan tindakan.

Riana Mashar menjelaskan tentang pandangan Hurlock mengenai pentingnya faktor kematangan emosi yang terkait dengan masa kritis perkembangan (critical priod),

10 Alwisol, Psikologi Kepribadian, (Malang:UMM Press, 2009), 1.

11 Riana Mashar, Emosi Anak Usia Dini dan Strategi Pengembangannya..., 29. yakni saat individu dinilai sudah siap menerima sesuatu dari luar. ${ }^{12}$ Selanjutnya kematangan yang telah dicapai dioptimalkan dengan pemberian rangsangan yang tepat. Seperti halnya perkembangan emosi, pengendalian pola reaksi emosi yang diinginkan perlu dimiliki oleh individu untuk menggantikan emosi yang tidak diinginkanatau tidakdiharapkan, halini dilakukan sebagai tindakan preventif. Perkembangan emosi tersebut biasa dikenal dengan kecerdasan emosi atau emotional intelligence. Kecerdasan emosi merupakan kemampuan untuk mengenali, mengolah, dan mengontrol emosi agar supaya individu mampu merespon secara positif setiap kondisi yang merangsang munculnya emosi.

Riana Mashar juga menjelaskan bahwa berbagai penelitian dibidang psikologi anak telah membuktikan bahwa anak yang memiliki kecerdasan emosi yang tinggi adalah anak-anak yang bahagia, percaya diri, populer, dan lebih sukses disekolah. Individu lebih mampu menguasai emosi, menjalin hubungan yang manis dengan orang lain, dapat mengelola stress, dan memiliki kesehatan mental yang baik. Golman dan SaloveyMayer merangkum aspek emosi menjadi lima ciri yaitu: pertama kemampuan mengenali emosi diri, 12 Ibid,32. 
kedua kemampuan mengelola dan mengekspresikan emosi, ketiga kemampuan memotivasi diri, keempat kemampuan mengenali emosi orang lain/empati, kelima kemampuan membina hubungan dengan orang lain. ${ }^{13}$

Kecerdasan emosional tidaklah ditentukan sejak lahir melainkan dapat dipengaruhi oleh pengalamanpengalaman yang dialami individu sehingga daripengalaman-pengalaman inilah individu dapat mengembangkan emosinya dan mengganti emosi yang tidak diinginkan dengan emosi yang diinginkan. Dalam sebuah dijelaskan, Endang menyatakan bahwa EQ dapat dikembangkan melalui dua hal yaitu kecakapan pribadi dan kecakapan sosial. ${ }^{14}$ Sehingga perkembangan emosi individu bisa didapatkan atau didorong oleh faktor dalam seperti rasa ingin tahu dan faktor luar seperti keluarga dan lingkungan.

\section{Kepribadian Introvert}

Kepribadian atau dalam bahasa Inggrisnya personality berasal dari bahasa Yunani kuno yakni prosopon atau persona yang artinya "topeng"

13 Riana Mashar, Emosi Anak Usia Dini dan Strategi Pengembangannya..., 34.

14 Hairul Umam, dan Rohmad Wahid Rhomdani, "Pengaruh Kecerdasan Emosional Terhadap Hasil Belajar Siswa Kelas X IPS SMAN 4 Jember",(Vol. 6. No. 12. Thn. 2010), 52 . yang biasa digunakan dalam sebuah pertunjukkan teater. Schultz menyatakan konsep awal personality adalah tingkah laku yang ditunjukkan kepada lingkungan sosial dan kesan mengenai diri yang diinginkan agar dapat ditangkap oleh orang lain. ${ }^{15}$

Individu tentulah memiliki emosi seperti rasa marah, rasa enggan, rasa senang, rasa nyaman, rasa sedih, bahkan rasa enggan yang membuat individu ingin menjauhi atau menarik diri dari hal tersebut. Akan tetapi yang menjadi pembeda diantara keduanya adalah bagaimana individu tersebut dapat mengontol, mengendalikan dan memahami emosi tersebut. Berbeda tipe kepribadian maka berbeda pula kemampuan pengelolaan emosinya. Begitu pula dengan tipe kepribadian introvert dan ekstrovert. Karena kepribadian merupakan karakteristik individu yang menyebabkan munculnya konsistensi perasaan, pemikiran, dan perilaku. Menurut Suryabata penggolongan tipe kepribadian introvert dan ekstrovert ini didasarkan pada perbedaan respon, kebiasaan, dan sifat-sifat individu dalam melakukan hubungan interpersonal, selain itu tipe kepribadian ini juga dapat menjelaskan posisi kecenderungan

15 Hidayat, Psikologi Kepribadian Dalam Konseling, (Bogor: Ghalia Indonesia, 2011), 6. 
individu berhubungan dengan reaksi dan tingkah laku. ${ }^{16}$

Carl Gustav Jung membagi karakter kepribadian berdasarkan orientasi minat dan sikap menjadi dua yakni Introvert dan Ekstrovet. Menurut Jung pribadi dengan tipe kepribadian introvert cenderung pendiam, pemalu, dan merasa tidak nyaman di situasi sosial. Carl Gustav Jung juga mengatakan bahwajika seseoranglebih mengarahkan ke dalam pengalaman obyektif, maka orang tersebut tergolong ke dalam tipe kepribadian ekstrovert. Sebaliknya jika seseorang mempunyai tipe kepribadian introvert, ia akan lebih mengarahkan pribadinya ke dalam pengalaman subyektif. ${ }^{17}$ Tipe kepribadian ekstrovert lebih mengarah pada pengalaman yang bersifat obyektif karena tipe kepribadian ini memusatkan perhatiannya ke dunia luar dan cenderung berinteraksi ketimbang terpaku pada persepsipersepsi pribadi sehingga kemampuan bersosialisasi ektrovert lebih baik. Sedangkan tipe kepribadian introvert cenderung bersifat subyektif karena

16 Komang Sri Widiantari, dan Yohanes Kartika Herdiyanto, "Perbedaan Intensitas Komunikasi Melalui Jejaring Sosial antara Tipe Kepribadian Ekstrovert dan Introvert pada Remaja”, Jurnal Psikologi Udayana, (Vol. 6. No. 12. Thn. 2013), 108.

17 Dina Satalina, Kecenderungan Perilaku Cyberbullying Ditinjau Dari Tipe Kepribadian Ekstrovert dan Introvert, Jurnal Ilmiah Psikologi Terapan, (Vol. 6. No. 12. Thn. 2014), 297. tipe kepribdian ini cenderung memusatkan perhatiannya pada dunia yang bersifat privasi dimana realita yang mucul berdasarkan pengamatan.

Penyataan Jung tersebut sudah banyak diketahui bahwa introvert merupakan tipe kepribadian yang tertutup, pendiam dan pemalu sedangkan tipe kepribadian ekstrovert merupakan tipe kepribadian yang terbuka, luwes, dan cenderung berbicara secara spontanitas. Akan tetapi tidak jarang anggota dari mereka tipe kepribadian introvert bersifat agresif, bandel, pembangkang atau bahkan menjadi seorang yang murung menarik diri dari lingkungannya dari interaksi sosial yang harusnya dihadapi. Hal ini tentunya tergantung kepada kecenderungan pribadi tiap individu. Dari penelitian Chandra dkk di Jember dapat diketahui bahwa adanya hubungan antara tipe kepribadian dengan perilaku seksual yang berisiko pada remaja, sehingga dapat disimpulkan bahwa remaja dengan tipe kepribadian introvert berpeluang 7,556 kali melakukan perilaku seksual hal ini dikarenakan tipe kepribadian memiliki kecenderungan yang tertutup di mana aktivitas tertutup ini berhubungan dengan unsure id manusia salah satunya kebutuhan seksual. Ini menjadikan 
salah satu bentuk patologis dari tipe kepribadian introvert yang tertutup. ${ }^{18}$

Dalam peneliatian Anggraeni dkk di Banjarmasin bahwa tipe kepribadian introvert memiliki kemungkinan 4,714 kali untuk mengalami kecanduan internet dibandingan dengan tipe kepribadian ekstovert dengan menghabiskan waktu 9 jam perminggu menggunakan internet untuk mencari teman dan bersosialisasi. Hal ini dikarenakan pribadi introvert akan lebih berorientasi pada stimulus internal seperti memperhatikan pikiran, suasan hati, dan reaksi yang terjadi dalam diri mereka sehingga hal-hal inilah yang menjadi pribadi introvert cenderung pendiam, pemalu, memiliki kontrol diri yang kuat, serta memiliki keterpakuan terhadap hal-hal yang terjadi dalam diri mereka. Oleh karena itu pribadi introvert menjadikan internet sebagai media bersosialisasi dan untuk mencari teman tanpa harus bertatap muka atau face to face dengan lawan bicaranya sehingga mereka merasa ini mampu mengurangi rasa canggung. ${ }^{19}$

18 Alvivo Chandra, Iis Rahmawati, dan Ratna Sari Hardiani, "Hubungan Tipe Kepribadian dengan Perilaku Seksual Berisiko Remaja di SMKN X Jember", (Vol. 2. No. 3.Thn. 2014), 497.

19 Muthia Anggraeni, Achyar Nawi Husain, dan Syamsul Arifin, "Hubungan Tipe Kepribadian Introvert dengan Kecanduan Internet Pada Siswa Kelas X di SMAN 1
Hal patologi dari tipe kepribadian introvert adalah dalam aspek perilaku yang didasari oleh sikap menarik diri atau (withdrawl) yang ditandai oleh kecenderung untuk menyendiri, apatis, mudah kecewa, mudah tunduk, mudah tersinggung, dan cenderung menyalahkan diri sendiri. Perilaku seperti ini bukanlah sebuah perilaku yang dibawa dari lahir melainkan sebuahhasildaripengintegrasianantara pola pikir dengan perilaku. Sehingga perilaku seperti ini dapat merugikan individu dalam hal perkembangan baik secara pribadi maupu secara sosial karena individu ini tidak secara optimal dalam mengembangkan potensi yang ada pada dirinya. ${ }^{20}$

Dari beberapa penjelasan diatas mengenai permasalahan pada tipe kepribadian introvert, maka penulis memberikan tawaran bimbingan dan konseling kelompok. Dengan tujuan, bimbingan dan konseling kelompok nantinya dapat menjadi wadah yang memfasilitasi pribadi introvert dalam bersosialisasi sehingga pribadi introvert tidak lagi menghabiskan waktu 9 jam perminggu menggunakan

Banjarmasin”, Berkala Kedokteran, (Vol. 10. No.Thn. 1. Thn. 2014), 5.

20 Faizatul Amilin, "Penerapan Konseling Kelompok Kognitif Perilaku untuk Menurunkan Kecenderungan Menarik Diri (Withdrawl), Pada Siswa Kelas X MIA4 SMA Negeri 1 Mantup Lamongan”, Jurnal BK Unesa, (Vol. 4. No. 3.Thn. 2014), 456. 
internet untuk mencari teman. Selain itu dengan bimbingan dan konseling kelompok juga dapat melatih dan lebih mengurangi pribadi introvert dalam perilaku menarik diri atau withdrawl dengan lingkungannya.

\section{E. Kepribadian Intovert}

Konseling kelompok menurut Carl Roger adalah hubungan yang dibangun antara konselor profesional dengan konseli yang dilandasi oleh kondisi-kondisi inti berupa ketulusan, empati, dan respek serta dilaksankan sebaik-baiknya denganmenggunakan keterampilan komunikasi yang efektif. Didalam layanan konseling yang lebih menekan pada komunikasi interpersonal yang melibatkan pikiran, perasaan dan perilaku serta berfokus pada saat ini dan sekarang. ${ }^{21}$ Corey menjelaskan beberapa tujuan konseling kelompok dan salah satunya adalah memperluas motivasi diri dan belajar untuk bisa menghadapi orang dengan peduli, perhatian, serta kejujuran. ${ }^{22}$ Sedangkan Mulkiyah dalam jurnalnya menjelaskan bahwa tujuan konseling kelompok adalah

21 Tri Sutanti, "Pelaksanaan Layanan Konseling Kelompok Pada Siswa Cerdas Istimewa di SMA Negeri Kota Yogyakarta”, Jurnal Konseling Gusjigang, (Vol. 1. No. 1.Thn. 2015), 4.

22 Gerald Corey, Theory and Practice of Counseling Eight edition, (USA: Broks/Cole Thompson, 2012), 29. berkembangan kemampuan sosialisasi siswa, khususnya kemampuan berkomunikasinya sehingga melalui konseling kelompok hal-hal yang menghambatsosialisasidankomunikasi diungkap dan didinamikakan sehingga menjadi sosialisasi dan komunikasi yang optimal. ${ }^{23}$

Berdasarkan penjelasan diatas, konseling kelompok merupakan layanan konseling yang dalam kegiatannya konselor profesional membangun hubungan kolaboratif dengan koseli yakni menggunakan keterampilan komunikasi yang efektif namun berlandaskan pada kondisikondisi berupa ketulusan, empati, dan respek. Sehingga layanan tersebut dapat mencapai tujuan konseling kelompok yakni belajar berinteraksi dengan orang lain dengan kepedulian, perhatian, dan kejujuran.

Didalam konseling kelompok pun terdapat sejumlah aturan ataupun asasasasyangsangatperlu diperhatikan oleh unsur yang terlibat dalam konseling kelompok tersebut. Fahmi \& Slamet mengelompokkan setidaknya terdapat enam asas yang harus diterapkan dalam konseling kelompok, asas-asas tersebut adalah a) asas kerahasiaan karena masalah yang dibahas dalam kegiatan

23 Mulkiyan, "Mengatasi Masalah Kepercayaan Diri Siswa Melalui Konseling Kelompok", Jurnal Konseling dan Pendidikan, (Vol. 5. No. 3.Thn. 2017), 138. 
konseling merupakan masalah pribadi, maka sudah sepatutnya setiap anggota menjaga kerahasiaan tersebut $b$ ) kesukarelaan yakni tanggapan anggota kelompok harus diterima dengan sukarela c) asas keterbukaan yakni seluruh anggota harus menyampaikan masalahnya secara terbuka tanpa ditutupi ataupun berbohong $d$ ) asas kegiatan yakni dalam proses kegiatannya dimaksudkan untuk menyelesaikan masalah sehingga tercapailah tujuan konseling kelompok e) asas kenormatifan sesama anggota harus menghormati pendapat anggota yang lain $\mathrm{f}$ ) asas kekinian yakni masalah yang dibahas dan yang akan diselesaikan adalah masalah yang saat ini terjadi dan dialami. ${ }^{24}$

Krunanto menjelaskan dalam bukunya bahwa Berg, Landert, dan Fall menjelaskan secara rinci peran kelompok dalam layanan bimbingan dan konseling adalah: a) kelompok sebagai lingkungan pencegahan $b$ ) elompok sebagai peluang dalam menemukan jati diri c) Kelompok sebagai sarana menemukan hal-hal baru d) Kelompok sebagai wadah dalam mendifinisikan kembali diri konseli e) Kelompok sebagai wahana

24 Nasrina Nur Fahmi \& Slamet, "Layanan Konseling Kelompok Dalam Meningkatkan Rasa Percaya Diri Siswa SMK Negeri 1 Depok Sleman”, Jurnal Hisbah, (Vol. 13. No. 1.Thn. 2016), 71. dalam mengembangkan kesadaran interpersonal f) Kelompok sebagai realitas pengujian laboratorium sosial g) Kelompok sebagai wadah bagi pribadi dalam memperoleh pengalaman hubungan yang bermakna h) Menekan pada kedinamisan dan pertumbuhan i) Dukungan lingkungan dalam kelompok sebagai terapi bagi individu. ${ }^{25}$

Emosi merupakan aspek sentral dalam kehidupan manusia, karena emosi selain berperan sebagai survival yang menumbuhkan rasa berjuang untuk bertahan hidup, emosi juga berperan sebagai energizer yang mana dengan perannya ini emosi dapat memberikan dorongan berupa stimulus rasa semangat dan gairah untu beraktivitas.Menurut Depdiknas emosi adalah luapan perasaan yang berkembang dan surutdalam waktu singkat. ${ }^{26}$ Menurut James emosi merupakan keadaan jiwa individu yang ditampakkan secara nyata pada perubahan jasmaninya. Adapun tokoh psikologi yakni Goleman menjelaskan bahwa emosi pada dasarnya adalah dorongan untuk bertindak, rencaan seketika untuk mengatasi masalah yang telah ditanamkan secara berangsurangsur dan emosi juga dimaksudkan

25 Kurnanto, Konseling Kelompok, (Bandung: Alfabeta, 2013), 2.

26 Depdiknas, Kamus Besar Bahasa Indonesia, (Jakarta: Balai Pustaka, 2005), 298. 
sebagai perasaan dan pikiran khas dimana suatu keadaan biologis dan psikologis serta serangkaian kecenderungan dalam bertindak. ${ }^{27}$

Menurut beberapa definisi diatas mengenai emosi, tegaskan bahwa emosi merupakan sebuah dorongan yang bisa berupa perasaan positif seperti senang dan bisa negatif seperi marah, sehingga dengan dorongan tersebut akan membawa individu dalam merencanakan sesuatu yang harus dilakukan bahkan pada saat bertindak.

Hurlock menjelaskan bahwa emosi yang dominan dapat mempengaruhi kepribadian individu yakni pada penyesuaian pribadi dan sosial. ${ }^{28}$ Begitu juga dengan Supeno yang menjelaskan bahwa emosi dapat memberi pengaruh pada ketidak seimbangan pikiran individu, apabia emosi menguasai diri individu maka kemampuan individu berfikir secara sehat akan cenderung berkurang atau bahkan hilang. ${ }^{29}$

James \& Lange menjelaskan bahwa emosi muncul karena pengaruh perubahan jasmani atau kegiatan

27 Goleman, Kecerdasan Emosional, Jakarta: Gramedia Pustaka, 2002), 7.

28 Hurlock, Development psychology: a life span approach, (Jakarta: Erlangga, 1973), 229.

29 Supeno, Kepemimpinan Damai, (Banda Aceh: Kementrian Negara Perencanaan Pembangunan Nasional BAPPENAS bekerjasama dengan World Bank, 2009), 345. individu sendiri. ${ }^{30}$ Sehingga dari sini dapat diketahui bahwa perubahan dan perkembang emosi seseorang tidak hanya dari diri sendiri tetapi juga dari luar diri individu seperti kegiatan seharhari, lingkungan, bahkan tuntutan pekerjaan atau perkuliahan.

Sedangkan untuk intelegensi para ahli tidak memiliki kesatuan pandang, meski begitu para ahli tetap menyusun teori intelegensi secara luas. Lynn menjelaskan bahwa terdapat dua tema utama yang uncul dalam diskusi intelegensi, yang pertama adalah tentang hakikat intelegensi, dan kedua adalah penyesuaian diri seseorang dengan lingkungannya. ${ }^{31}$

Emotional intellegeance atau kecerdasan emosional berfungsi untuk menerangkan kulitas-kualitas emosional yang tampaknya penting bagi keberhasilan. Kualitas-kualitas ini antara lain adalah: empati, mengungkapkan dan memahami perasaan, mengendalikan amarah, kemandirian, kemampuan menyesuaikandiri, diskusi,kemampuan memecahkan masalah antar pribadi,

30 Jamaludin, "Pengaruh Kecerdasan Intelektual, Kecerdasan Emosional, Dan Kecerdasan Spiritual Terhadap Etika Mahasiswa Akuntansu Fakultas Ekonomi Universitas Tadulako", Jurnal Pamator, (Vol. 4. No. 1.Thn. 2011), 12.

31 Wilcox, Psikologi Kepribadian Analisis Seluk-beluk Kepribadian Manusia, (Jogjakarta: Ircisod, 2013), 189. 
ketekunan, kesetiakawanan, keramahan, sikap hormat. Dalam arti lain, kecerdasan emosi merupakan kemampuan individu untuk mengelola dan mengekspresikan emosinya kedalam bentuk tindakan.

Kepribadian atau personality merupakan tingkah laku yang ditunjukkan kepada lingkungan sosial dan kesan mengenai diri yang diinginkan dan dapat ditangkap oleh orang lain. Carl Gustav Jung membagi tipe kepribadian menjadi dua tipe kepribadian pertama tipe kepribadian yang berorientasikan pada kesadaran atau ekstrovert dan kedua tipe kepribadian yang berorientasi pada ketidaksadaran atau introvert. ${ }^{32}$ Pribadi dengan tipe kepribadian ekstrovert cenderung pada pengalaman yang bersifat obyektif yang mana pusat perhatiannya ke dunia luar dan cenderung berinteraksi ketimbang terpaku dengan persepsi-persepsi pribadi. Sedangkan tipe kepribadian introvert cenderung mengarahkan diri pada pengalaman yang bersifat subyektif dengan pusat perhatiannya pada dunianya yang cenderung privasi dimana realita yang muncul berdasarkan pengalaman.

Tipe kepribadian introvert dan ekstrovert bukan sesuatu yang bersifat mutlak, karena pada dasarnya tidak

32 Alwisol, Psikologi Kepribadian...,47. ada individu yang selamanya bertipe ektrovert ataupun introvert. ${ }^{33}$ Berfokus pada tipe kepribadian introvert yang berorientasikan pada ketidaksadaran serta bersifat subyektif. Suryabrata menjelaskan bahwa kecenderungan tipe kepribadian ekstrovert dan introvert terdapat perbedadaanperbedaan pada reaksi terhadap lingkungan yang mana sekaligus dapat menggambarkan keunikan individu dalam bertingkah laku terhadap suatu stimulus. ${ }^{34}$ Qomariyah menunjukkan bahwa pribadi introvert memiliki satu jenis pemahaman yakni pemahaman relasional yang mana pemahaman ini mendorong pribadi introvert memahami masalah, kemudian merencakan penyelesaian yang matang melalui proses perdebatan perspepsipersepsi pribadi yang dialami. Begitu pula dalam merealisasikan rencananya akan cenderung berhati-hati dan menargetkan hasil yang sempurna atau perfeksionis. Tidak sampai disitu setelah melakukan penyelesaian masalah pribadi introvert akan melakukan evaluasi atas masalahya. ${ }^{35}$

33 Grita Ratriana Melinda, "Kontrol Emosi Pada Mahasiswa Yang Memiliki Tipe Kepribadian Introvert di Yogyakarta”..., 280.

34 Sumadi Suryabrata, Psikologi Kepribadian, (Jakarta: Rajawali, 2000), 70.

35 Nurul Qomariyah, "Profil Pemahaman Siswa Dalam Memecahkan Masalah Persamaan Kuadrat Ditinjau Dari Perbedaan Kepribadian Extrovert dan Introvert", Jurnal Apotema, (Vo. 2. No. 1. Thn. 2016), 91. 
Sifat-sifat pada pribadi introvert yang dinilai menjadi sebuah kekurangan, menjadikan pribadi introvert. Mengatasi permasalahan diatas, pada era saat ini menggunakan konseling kelompok dapat dilihat bahwa pribadin introvert memiliki keunikan tersendiri sehingga mereka mampu masuk pada lingkungan baru yang pada mulanya menimbulkan ketidaknyamanan. Hal ini dapat dilihat melalui penelitian-penelitian yang berfokus pada keunikan pribadi introvert. Pribadi introvert yang dikenal sebagai pribadi yang kaku adakalanya pribadi introvert ini dapat berbaur dengan lingkungan baru meskipun untuk itu mereka membutuhkan waktu lebih jika dibandingkan dengan pribadi ekstrovert.

Wahyu Rahmat subyek yang berkepribadian introvert akan timbul rasa percaya ketika ia memiliki hubungan yang dekat atau memiliki kesamaan dengan orang lain, namun terhadap orang yang lebih berpengalaman atau memiliki pengetahuan lebih dari dirinya, akan menimbulkan rasa percaya yang lebih dan memudahkannya untuk bersifat terbuka karena orang demikian dinilainya mampu menjaga rahasia. ${ }^{36}$

36 Wahyu Rahmat, "Pengaruh Tipe kepribadian dan Kualitas Persahabatan Dengan Kepercayaan Pada Remaja Akhir", E-Journal Psikologi, (Vol. 2. No. 2.Thn. 2014), 209.
Rahmawati dkk menggunakan teknik cooperative play untuk mempengaruhi interaksi sosial anak yang bertipe kepribadian introvert. Pada tipe kepribadian introvert kemungkinan pertama yang melatarbelakangi permasalahan interaksi sosial pribadi introvert adalah self concept yang menggambarkan diri mereka lebih eksklusif ketimbang orang lain. Untuk itu teknik cooperative playing diterapkan. Teknik ini digunakan dalam ranah konseling kelompok dan permainan ini sering dikenal dengan dengan permainan sosial. Jadi permainan cooperative playing merupakan permainan secara beregu dan dilaksanakan selama seminggu sekali pada mata pelajaran olahraga, dengan kegiatan bermain ini dapat membantu membiasakan pribadi introvert dalam berinteraksi.

Faizatul Amilin mengaplikasikan konseling kelompok dengan pendekatan kognitif perilaku dengan tujuan konseling mengurangi atau menurunkan kecenderungan menarik diri (withdrawl) pada pelajar, strategi yang digunakan adalah cognitive restructuring dan self monitoring yang mana strategi tersebut membantu individu untuk menetapkan hubungan antara persepsi dengan kognisi dan emosi dengan perilaku berdasarkan persepsi meningkatkan diri atau 
mengganti pikiran negatif yang ada dengan pikiran positif sehingga individu akan terbantu dalam berpikir secara lebih rasional. ${ }^{37}$

Corey berasumsi bahwa dalam konseling kelompok memiliki empat tahapan antara lain intial stage pada tahapan awal ini anggota kelompok akan membuka diri dengan memperkenalkan diri dengan tujuan untuk membangun atmosfer dalam kelompok meski pada tahap ini masih banya kecanggungan, transition stage pada tahap kedua ini pengamatan keamanan lingkungan (situasi konseling kelompok) sehingga pada tahap ini anggota akan belajar mengekspresikan diri dengan menyampaikan masalah, working stage pada tahap ini garis pemisah dalam kelompok ditiadakan dalam artian setiap anggota memberikan masukan, nasihat, ataupun mengkoreksi dengan baik anggota lain dan anggota yang mendapat kritik diharapkan mampu menerima masukkan dengan baik pula, selanjutnya adalah terminating stage tahapan akhir yang mana setiap anggota akan berpisah dalam konteks konseling kelompok, dalam tahap ini diisi dengan evaluasi masalah

37 Faizatul Amilin, "Penerapan Konseling Kelompok Kognitif Perilaku untuk Menurunkan Kecenderungan Menarik Diri (Withdrawl), Pada Siswa Kelas X MIA4 SMA Negeri 1 Mantup Lamongan..., 460. yang belum selesai serta meninjau pengalaman kelompok sehingga setiap anggota kelompok akan memberi dan menerima umpan balik. ${ }^{38}$

Pada artikel ini, penulis mencoba memberikan tawaran bimbingan konseling kelompok dengan tujuan adanya konseling kelompok ini mampu menjadi wadah yang memfasilitasi pribadi introvert untuk bersosialisasi danmengekspresikanemosinya. Dalam tawaran konseling kelompok ini, terdiri dari 5 sampai 8 orang anggota dengan 2 konselor. Setiap anggota memiliki orientasi masalah dan tujuan dasar yang sama dan mereka setiap anggota bersedia menjelajahi masalah mereka serta mengembangkan tujuan mereka dalam kelompok konseling ini yakni memiliki kesulitan dalam bersosialisasi sehingga ingin menciptakan diri yang baru dengan mencoba lingkungan baru dalam sebuah kelompok baru. Para anggota kelompok konseling ini akan diberikan perlakuan selama 6 kali pertemuan dengan intensitas pertemuan satu kali pertemuan dalam seminggu. Sehingga konseling kelompok terdiri dari beberapa tahapan, secara lebih spesifik penulis menyajikan tiap tahapan dalam bentuk table berikut:

38 Tri Sutanti, "Pelaksanaan Layanan Konseling Kelompok Pada Siswa Cerdas Istimewa di SMA Negeri Kota Yogyakarta..., 5 . 


\begin{tabular}{|c|c|c|}
\hline Tahapan & Konselor & Konseli \\
\hline $\begin{array}{l}\text { Tahap I (Initial Stage) } \\
\text { Tahap ini dilakuka } \\
\text { dalam satu kali } \\
\text { pertemuan, yang } \\
\text { meliputi: } \\
1 . \\
\text { Memperkenalkan } \\
\text { diri (konselor dan } \\
\text { konseli) } \\
2 . \\
\text { Menyampaikan } \\
\text { pengalaman } \\
\text { 3. Merumuskan } \\
\text { tujuan } \\
4 . \\
\text { kontrak forum } \\
\text { Tahap ini dilakukan } \\
\text { dalam satu kali } \\
\text { peretemuan. }\end{array}$ & 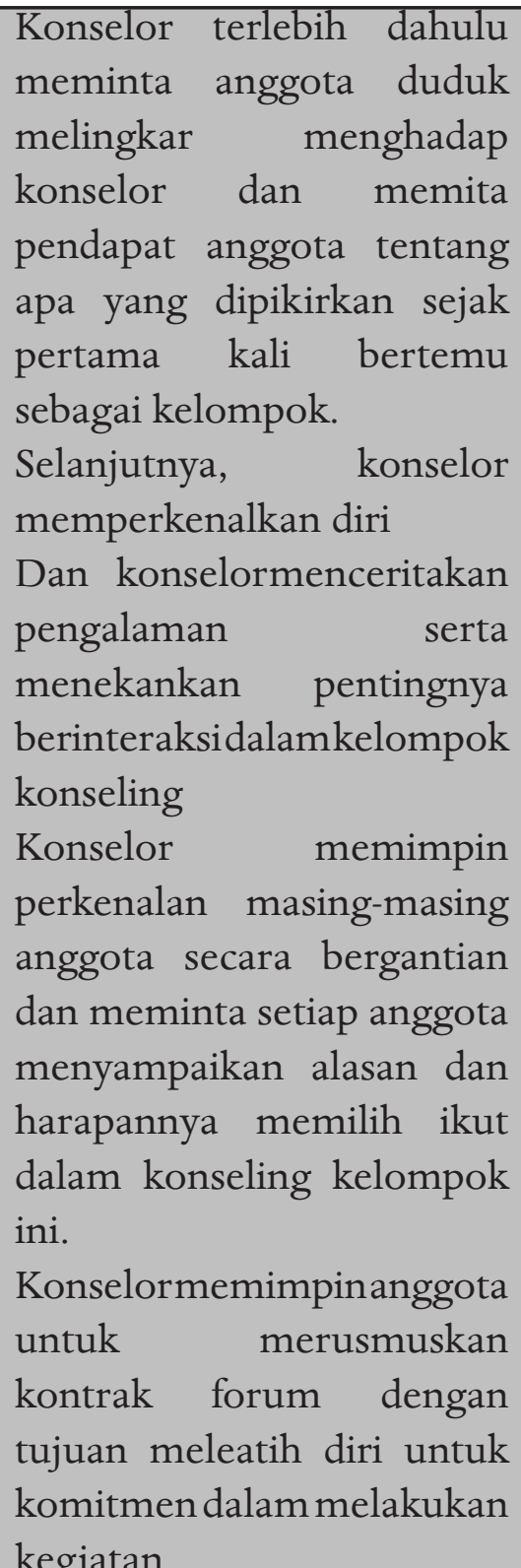 & $\begin{array}{l}\text { Konseli memeperkenalkan } \\
\text { diri kepada konselor dan } \\
\text { anggota kelompok lainnya. } \\
\text { Konseliranenceritakan } \\
\text { pengalamannya } r \text { baik } \\
\text { dalam konseli kelompok } \\
\text { sebelumnya (jika anggota } \\
\text { pernah mengikuti konseling } \\
\text { kelompok sebelumnya) atau } \\
\text { pengalaman dalam kegiatan } \\
\text { lainnya. Dan menyampaikan } \\
\text { alasan serta harapannya } \\
\text { mengikuti konseling } \\
\text { kelompok ini. } \\
\text { Masing-masing anggota } \\
\text { menyampaikan } \\
\text { tentang hal-hal yang perlu } \\
\text { diperhatikan supaya tujuan } \\
\text { konseling kelompok dapat } \\
\text { tercapai secara optimal }\end{array}$ \\
\hline
\end{tabular}




\begin{tabular}{|c|c|c|}
\hline $\begin{array}{l}\text { Tahapan II (Transition } \\
\text { stage) } \\
\text { Anggota mulaibelajar } \\
\text { mengekspresikan diri } \\
\text { dan menyampaikan } \\
\text { masalah. Sehingga } \\
\text { tahap transisi ini } \\
\text { dilakukan dalam dua } \\
\text { kali pertemuan. } \\
\text { - Pertemuan } \\
\text { I: diawali dengan } \\
\text { penyampain } \\
\text { kecemasan dan } \\
\text { kegelisahan } \\
\text { anggota. } \\
\text { - Pertemuan } \\
\text { II: menyampaikan } \\
\text { perkembangan } \\
\text { masalah }\end{array}$ & 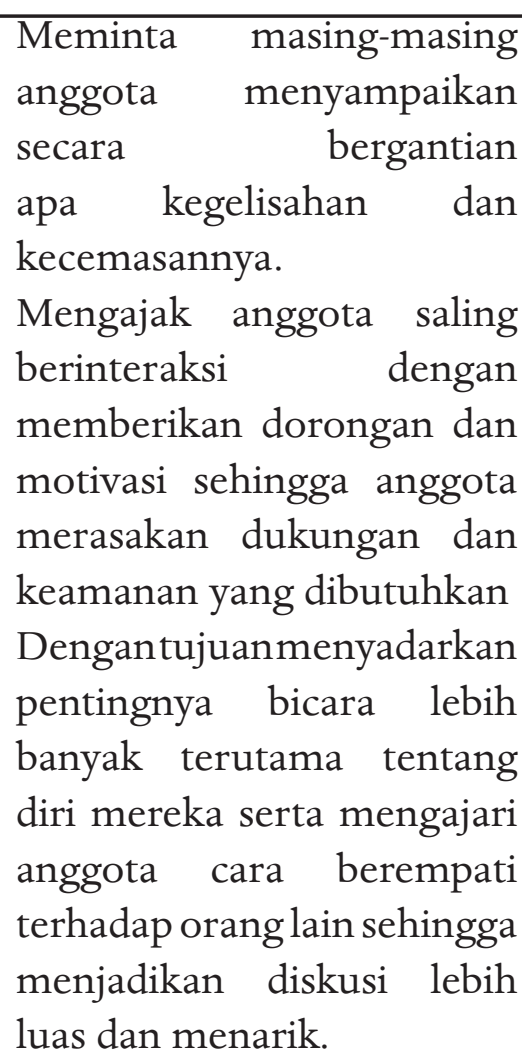 & $\begin{array}{l}\text { Anggota I menyampaikan } \\
\text { kegelisahan dan } \\
\text { kecemasannya dan anggota } \\
\text { yang lain memberikan } \\
\text { dorongan kepada anggot } \\
\text { I bisa berupa kata-kata } \\
\text { semangat dan lain-lain } \\
\text { Kemudian dilanjutkan } \\
\text { dengan anggota yang lain, } \\
\text { secara bergantian. }\end{array}$ \\
\hline $\begin{array}{l}\text { Tahap III (Working } \\
\text { stage) } \\
\text { Setiap anggota } \\
\text { memberikan } \\
\text { masukan, } \\
\text { nasihat, ataupun } \\
\text { mengkoreksi dengan } \\
\text { baik anggota lain } \\
\text { dan anggota yang } \\
\text { mendapat kritik } \\
\text { diharapkan mampu } \\
\text { menerima masukkan } \\
\text { dengan baik pula }\end{array}$ & $\begin{array}{l}\text { Konselor membantu } \\
\text { anggota mengungkapkan } \\
\text { masalah mereka lebih dalam } \\
\text { dan menyampaikan usaha } \\
\text { yang sudah dilakukan dalam } \\
\text { mengatasi masalahnya } \\
\text { tersebut. }\end{array}$ & $\begin{array}{l}\text { Anggotasatumenyampaikan } \\
\text { masalah dan upaya } \\
\text { yang telah dilakukan, } \\
\text { kemudian anggota II, III, } \\
\text { dst menyampaikan ide } \\
\text { atau tanggapan mengenai } \\
\text { kegelisahan anggota I baik } \\
\text { berupa kritik atau saran } \\
\text { yang harus dilakukan } \\
\text { anggota I untuk mengatasi } \\
\text { kegelisahannya. }\end{array}$ \\
\hline
\end{tabular}




\begin{tabular}{|c|c|c|}
\hline $\begin{array}{l}\text { Tahap IV } \\
\text { Evaluasi masalah } \\
\text { yang belum selesai } \\
\text { serta meninjau } \\
\text { pengalaman } \\
\text { kelompok sehingga } \\
\text { setiap anggota } \\
\text { kelompok akan } \\
\text { memberi dan } \\
\text { menerima umpan } \\
\text { balik. }\end{array}$ & $\begin{array}{l}\text { Meminta setiap anggota } \\
\text { menyampaikan kegelisahan } \\
\text { atau kecemasan yang masih } \\
\text { dirasakan. } \\
\text { Disini konselor } \\
\text { memberikan model } \\
\text { pembaharuan konseling } \\
\text { kelompok dengan } \\
\text { meminta anggota } \\
\text { kelompok menuliskan } \\
\text { idola dan alasannya mereka } \\
\text { mengidolakan seseorang } \\
\text { tersebut, dan meminta } \\
\text { anggota mencatatat } \\
\text { target atau hal-hal yang } \\
\text { ingin dicapai baik dalam } \\
\text { jangka panjang maupun } \\
\text { jangka pendek. Kemudian } \\
\text { meminta anggota } \\
\text { menyampaikannya ditengah } \\
\text { forum. } \\
\text { Dengan tujuan, supaya } \\
\text { anggota tidak selalu } \\
\text { terpaku pada kecemasan } \\
\text { dan kegelisahan yang } \\
\text { dirasakan tetapi juga } \\
\text { menyadarkan bahwa } \\
\text { mereka memiliki banyak } \\
\text { hal yang harus dilakukan } \\
\text { dan dikembangkan. }\end{array}$ & 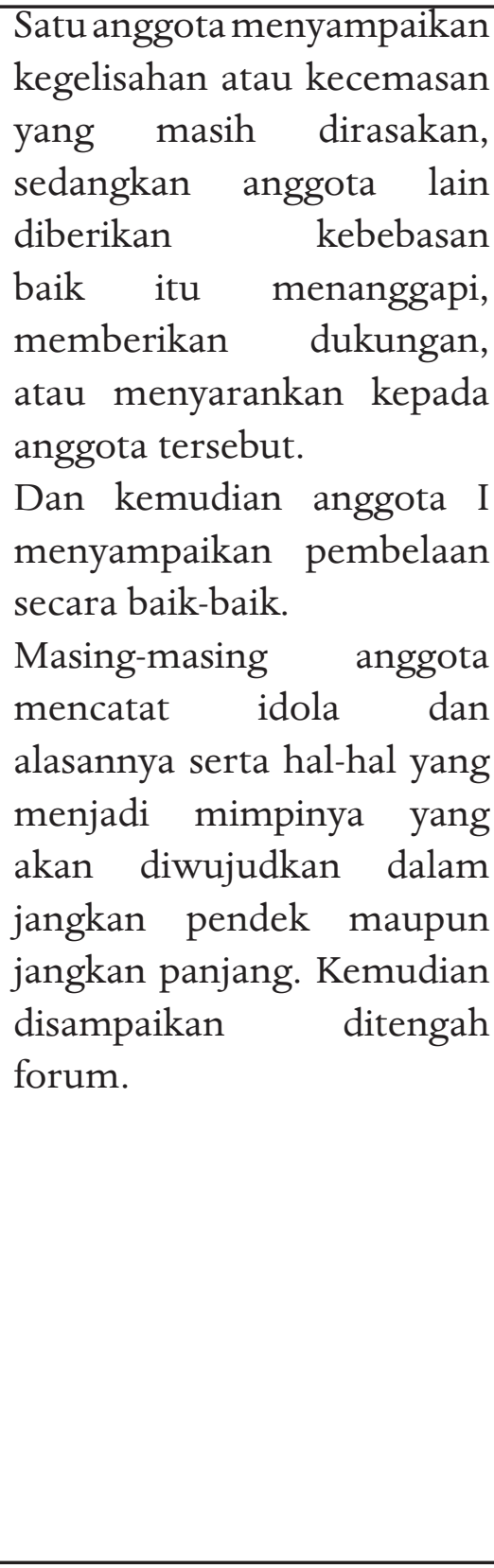 \\
\hline
\end{tabular}

Sehingga dengan konseling mulai mengenal anggota kelompok kelompok (group counseling) yang dan memperkenalkan diri kepada menekan pada keangktifan anggota anggota kelompok, memahami dalam berbicara tentag dirinya masalahnya dan anggota kelompok, mampu memberikan kesempatan mendiskusikan dengan memberikan bagi pribadi introvert dengan waktu dan menerima pendapat ataupun yang lebih dibutuhkannya untuk solusi, merealisasikan rencana memahami diri serta lingkungan perubahan, sampai pada evaluasi 
tindakan dan perubahan. Dengan demikian, konseling kelompok (group counseling) membantu pribadi introvert mempermudah diri membuat hubungan keterbukaan dengan orang lain disekitarnya meski untuk itu ia memerlukan beberapa waktu, karena pada nyatanya konseling kelompok mampu menjadisalah satu wadah yang dapat memfasilitasi pribadi introvert dalam beradaptasi dan mengembangkan diri dengan lingkungan baru.

\section{F. Penutup}

Emosi merupakan aspek sentral bagi kehidupan, karena fungsinya sebagai dorongan dan semangat untuk individu melakukan suatu tindakan maupun aktifitas. Karena begitu penting individu perlu mengontrol dan mengembangkan emosi yang ada. Perkembangan emosi individu dapat dipengaruhi dari dalam diri dan juga dari lingkungan. Perkembangan emosi ini untuk menggantikan emosi yang tidak diinginkan dengan emosi yang diharapkan. Individu yang mampu mengelola dan mengembangkan emosinya dengan akan mencapai suatu titik dimana titik tersebut dinamakan kecerdasan emosi.

Berbeda tipe kepribadian maka berbeda pula emosinya. Begitu juga dengan tipe kepribadian introvert dan ekstrovert. Jika ekstrovert merupakan tipe kepribadian yang supel dan mudah bersosialisasi, berbeda dengan introvert yang identik dengan sifatnya yang kaku, tertutup, dan sulit untuk beradaptasi. Namun bukan berarti ptibadi introvert tidak dapat bersosialisasi, mereka hanya akan memikirkan cara yang tepat supaya mereka dapat berbaur dengan lingkungan.

Maka sangat diperlukan adanya tawaran bimbingan konseling kelompok dengan tujuan adanya konseling kelompok ini mampu menjadi wadah yang memfasilitasi pribadi introvert untuk bersosialisasi dan mengekspresikan emosinya. Dalam bimbingan dan konseling kelompok yang penulis tawarkan tidak hanya membantu pribadi introvert bersosialisasi tetapi juga menyadarkan bahwa ia mampu mencapai lebih banyak hal yang direncanakan dari sekarang. Sehingga sejalan dengan hakikat bimbingan dan konseling pribadi-sosial yang menjadikan individu mempunyai pengaruh baik untuk diri sendiri maupun orang lain sehingga adanya timbale balik antara keduanya. 


\section{Daftar Pustaka}

Alfatih, Annajmi, Taufik, dan Ibrahim, Indra, "Peningkatan Kematangan Emosi Anak Bungsu Melalui Layanan Bimbingan Kelompok", Jurnal Konseling dan Pendidikan, (Vol. 4. No. 1. Thn. 2015)

Amilin, Faizatul, “Penerapan Konseling KelompokKognitif Perilakuuntuk Menurunkan Kecenderungan Menarik Diri (Withdrawl), Pada Siswa Kelas X MIA4 SMA Negeri 1 Mantup Lamongan", Jurnal BK Unesa, (Vol. 4. No. 3. Thn. 2014) Anggraeni, Muthia, dan Arifin, Syamsul, "Hubungan Tipe Kepribadian Introvert dengan Kecanduan Internet Pada Siswa Kelas X di SMAN 1 Banjarmasin”, Berkala Kedokteran, (Vol. 10. No. Thn. 1. Thn. 2014)

Baskara, Adya, Soetjipto, P, Helly, dan

Nuryati Atamimi, "Kecerdasan EmosiDitinjauDariKeikutsertaan Dalam Program Meditasi”, Jurnal Fakultas Psikologi UGM, (Vol. 35. No. 2. 2015)

Chandra, Alvivo, Rahmawati, Iis, dan Hardiani, Sari, Ratna, "Hubungan Tipe Kepribadian dengan Perilaku Seksual Berisiko Remaja di SMKN X Jember", (Vol. 2. No. 3. Thn. 2014)
Corey, Gerald, Theory and Practice of Counseling Eight edition, (USA: Broks / Cole Thompson, 2012)

Depdiknas, Kamus Besar Bahasa Indonesia, (Jakarta: Balai Pustaka, 2005)

Fahmi, Nur, Nasrina \& Slamet, "Layanan Konseling Kelompok Dalam Meningkatkan Rasa Percaya Diri Siswa SMK Negeri 1 Depok Sleman", Jurnal Hisbah, (Vol. 13. No. 1. Thn. 2016)

Goleman, Kecerdasan Emosional, Jakarta: Gramedia Pustaka, 2002) Hidayat, Psikologi Kepribadian Dalam Konseling, (Bogor: Ghalia Indonesia, 2011)

Hurlock, Development psychology: a life span approach, (Jakarta: Erlangga, 1973)

Jamaludin, "Pengaruh Kecerdasan Intelektual, Kecerdasan Emosional, Dan Kecerdasan Spiritual Terhadap Etika Mahasiswa Akuntansu Fakultas Ekonomi Universitas Tadulako", Jurnal Pamator, (Vol. 4. No. 1. Thn. 2011)

Kurnanto, Konseling Kelompok, (Bandung: Alfabeta, 2013)

Mashar, Riana, Emosi Anak Usia Dini dan Strategi Pengembangannya, (Jakarta: Kencana, 2011) 
Melinda, Ratriana, Grita, "Kontrol Emosi Pada Mahasiswa Yang Memiliki Tipe Kepribadian Introvert di Yogyakarta”, Jurnal Riset Mahasiswa Bimbingan dan Konseling, (Vol. 3. No. 7. Thn. 2017)

Mulkiyan, "Mengatasi Masalah Kepercayaan Diri Siswa Melalui Konseling Kelompok”, Jurnal Konseling dan Pendidikan, (Vol. 5. No. 3. Thn. 2017)

Nursalim, Muhammad, Bimbingan dan Konseling Pribadi-Sosial, (Yogyakarta: Ladang Kata, 2012)

Qomariyah, Nurul, "ProfilPemahaman

Siswa Dalam Memecahkan

Masalah Persamaan Kuadrat

Ditinjau Dari Perbedaan

Kepribadian Extrovert dan

Introvert”, Jurnal Apotema, (Vo. 2.

No. 1. Thn. 2016)

Rahmat, Wahyu, "Pengaruh Tipe kepribadian dan Kualitas Persahabatan Dengan

Kepercayaan Pada Remaja Akhir”, E-Journal Psikologi, (Vol. 2. No. 2. Thn. 2014)

Rosida, Edwina dan Astuti, Puji, Tri, "Perbedaan Penerimaan Teman Sebaya Ditinjau Dari Tipe Kepribadian Ekstrovert dan Introvert”, Jurnal Empati, (Vol. 4. No. 1. Thn. 2015)
Satalina, Dina, Kecenderungan Perilaku Cyberbullying Ditinjau Dari Tipe Kepribadian Ekstrovert dan Introvert, Jurnal Ilmiah Psikologi Terapan, (Vol. 6. No. 12. Thn. 2014)

Supeno, Kepemimpinan Damai, (Banda Aceh: Kementrian Negara Perencanaan Pembangunan NasionalBAPPENASbekerjasama dengan World Bank, 2009)

Suryabrata, Sumadi, Psikologi Kepribadian, (Jakarta: Rajawali, 2000)

Sutanti, Tri, "Pelaksanaan Layanan Konseling Kelompok Pada Siswa Cerdas Istimewa di SMA Negeri Kota Yogyakarta”, Jurnal Konseling Gusjigang, (Vol. 1. No. 1. Thn. 2015)

Umam, Hairul, dan Rhomdani, Wahid, Rohmad, "Pengaruh Kecerdasan Emosional Terhadap Hasil Belajar Siswa Kelas X IPS SMAN 4 Jember”, (Vol. 6. No. 12. Thn. 2010)

Widiantari, Sri, Komang, dan Herdiyanto, Kartika, Yohanes, "PerbedaanIntensitasKomunikasi Melalui Jejaring Sosial antara Tipe Kepribadian Ekstrovert dan Introvert pada Remaja”, Jurnal Psikologi Udayana, (Vol. 6. No. 12. Thn. 2013) 
al Tazkiah, Volume 7, No. 1, Juni 2018

Wilcox, Psikologi Kepribadian Analisis Seluk-beluk Kepribadian Manusia, (Jogjakarta: Ircisod, 2013)
Yusuf, Syamsu dan Nurihsan, Juntika, Landasan Bimbingan dan Konseling, (Jakarta: PT Rosda Karya, 2008) 